\section{Bangladesh plans to exploit its natural gas}

BANGLADESH has met with little success in exploring for essential minerals. But it has found natural gas in commercially exploitable quantities. Seven gas fields, all in the East, have so far been identified, but few wells have been drilled in these fields and consequently the data required to evaluate the total exploitable quantity of gas are limited. A total of about $9.36 \times 10^{\circ}$ standard cubic feet of gas has been estimated in all these reserves, of which the two main fields are Tatas with reserves of about $2.2 \times 10^{12}$ st. cu. ft and Bakhrabad with about $2.8 \times 10^{12}$ st. cu. ft. Knowledgeable experts reckon that besides the proven reserves, there may be an additional quantity of about $11.30 \times 10^{12}$ st. cu. ft, bringing the total to about $20 \times 10^{12}$ st. cu. ft of gas in fields already discovered.

Tatas is the only field being exploited extensively at present. A 14-inch diameter 55-mile-long pipeline feeds three power stations, one fertiliser factory, the industrial and domestic consumptions in Dacca and some other areas along its route. The Chhatak cement factory, the Fenchuganj fertiliser plant and the Shahjibazar power station are each supplied from a separate field nearby. On the whole about 100 million st. cu. ft of gas is presently being used in a day by four power stations, two fertiliser plants, 231 industrial units, 934 commercial units and 43,500 domestic consumers.

Bangladesh gas is one of the purest natural gases composed of $95 \%$ to $99 \%$ methane, very little higher hydrocarbons and inert gases, carbon dioxide, and traces of sulphur. It has a calorific value of $1,050 \mathrm{BTU} / \mathrm{st}$. cu. ft.

Bangladesh at present needs to import annually about $1.40 \times 10^{6}$ tons of crude oil besides coal and other fuels, involving about $\$ 100$ million in foreign exchange. Five years hence import requirements are expected to doubleso the government has undertaken a programme to maximise the use of natural gas. Gas is the only source of energy capable of rapidly replacing the bulk of imported fuel.

An interesting prospect would be the replacement of kerosene by methanol produced from Bangladesh natural gas in household applications such as in cooking and lighting. The fact that methanol is toxic and burns with a flame invisible in daytime makes it necessary to investigate the possibility of suitable additives to methanol delivered to households and to design an appropriate system of distribution and handling. Natural gas can also be an excellent raw material for export. It can be transported in natural form by pipelines or in liquid form, by refrigerated truck, railcar or tanker. The liquid is reconverted into gas at the point of delivery without affecting the thermal efficiency. It has, however, been reported that process efficiency, in terms of BTU content, of liquefaction is about $86 \%$, whereas that of conversion into methanol is only $56 \%$.

M. Kabir

\title{
USSR Academy plans for 1990
}

According to current Soviet doctrine, the Academy of Sciences has the task of co-ordinating the research efforts of the whole Union and ensuring their application in "accelerating scientific and technical progress". This year's Annual General Meeting of the Academy, falling as it does within the jubilee year of the October Revolution, placed unusually great emphasis on the practical sides of the Academy's work.

In his report, Academician Anatolii Aleksandrov, President of the Academy, noted that a forecast of the development of particular (unspecified) fields of science and technology had been prepared up to 1990 . "Important practical recommendations" had been made and were being implemented, aimed at the "socialist integration" of the Comecon block - an ideal which. although somewhat de-emphasised in the current Five Year Plans, still remains an ultimate desideratum.

Turning from planning to more concrete matters, Aleksandrov noted that several new Institutes had been opened, including an applied physics institute (in Gor'kii), an institute for the comprehensive exploitation of mineral resources, and an institute for molecular genetics. These last two subjects are specifically mentioned in the "Fundamental Directions for Science and Technology" of the current Five-Year Plan; indeed, molecular genetics was suddenly upgraded half-way through the previous plan (in May, 1974), an unsual event which must have proved extremely perturbing to those responsible for the more detailed aspects of State planning.

Other topics mentioned in the "Fundamental Guidelines" include space research and the development of new chemicals. These interests were specially mentioned in the report by Georgii Skryabin, Chief Academic Secretary of the Academy, announcing the winners of the Academy's gold medals. One of the winners could not, however, come forward to receive his medal; cosmonaut Georgii Grechko was unavoidably detained aboard Salyut-6.

\section{Marinov recants}

Stefan Marinov, the Bulgarian antirelativist, caused a considerable stir earlier this year when his book Eppur si Muove came out with a preface signed by Academician Andrei D. Sakharov.

According to verbal messages relayed by friends, Sakharov repudiated the preface (see Nature 271, 296-297; 1978). Marinov, however, was unwilling to accept these reports, and, leaving his Belgian exile, flew to Moscow as a week-end tourist. $\mathrm{He}$ reports the outcome in a letter to Nature's correspondent on Soviet affairs:

"Dr Sakharov told me that he had never given any oral message which could be understood as a consent that the foreword written by me and sent about a year ago to him could appear
The highest award of the Academythe Lomonosov gold medals, had been announced earlier this year; however, a formal announcement was made by Academician Aleksandrov. The Lomonosov medals go, traditionally, to one Soviet and one foreign scientist each year; this time they went to Mikhail Lavrent'ev for work in mathematics and to Linus Pauling for his work in chemistry and biochemistry.

The vast extent of the Academy's work was implicit in all the reports. The Academy now includes more than 250 institutes.

Vera Rich

signed with his name. He had expressed only a general sympathy towards me. $\mathrm{He}$ wishes to be no more involved in my fight for the restoration of absolute space-time. I begged him to publish clearly in the press his opinion of my theory; however he refused to do this, because he is dedicating his time to other problems. 'Our ways have crossed once' he said 'and I should prefer that they do not cross another time'.

"I presented to Dr Sakharov my excuses for the highly unpleasant incident of this foreword, and I do this publicly with the present declaration.

"Sakharov's foreword has appeared only in the 1000 copies already published. The foreword will be removed from the 4000 copies which will be printed as 'second edition'.". . . 